\title{
MEKANISME PENENTUAN GANTI RUGI ATAS KERUSAKAN LINGKUNGAN HIDUP OLEH PERUSAHAAN: PENDEKATAN PENYELESAIAN SENGKETA KEPERDATAAN
}

\author{
I Ketut Widyantara Putra, Fakultas Hukum Universitas Udayana, e-mail: \\ widyantaraputra99@gmail.com \\ Kadek Agus Sudiarawan, Fakultas Hukum Universitas Udayana, e-mail: \\ agus_sudiarawan@unud.ac.id
}

doi: https://doi.org/10.24843/KS.2020.v08.i10.p14

\begin{abstract}
ABSTRAK
Penulisan artikel jurnal ini bertujuan untuk mengetahui bagaimana model penyelesaian sengketa lingkungan hidup melalui jalur keperdataan dan untuk mengetahui mekanisme dan pengaturan mengenai penentuan ganti rugi atas kerugian yang dialami dalam sengketa lingkungan hidup. Metode yang digunakan dalam penelitian hukum ini adalah metode penelitian hukum normatif, dengan menerapkan teknik deskripsi analisis yang menjawab permasalahan berdasarkan analisis bahan hukum serta perundang-undangan. Hasil penelitian menunjukan bahwa, terdapat 2 model penyelesaian sengketa lingkungan hidup melalui jalur keperdataan yang dapat ditempuh, yaitu jalur litigasi dan jalur nonlitigasi. Pada penyelesaian sengketa melalui jalur litigasi, dalam mengajukan gugatan dapat dilakukan melalui beberapa model gugatan, yaitu Gugatan Perorangan, Gugatan Perwakilan Kelompok, dan Gugatan Organisasi Lingkungan Hidup. Sedangkan, pada jalur non-litigasi dapat dilakukan dengan cara negosiasi, mediasi, konsiliasi, dan arbitrase. Mengenai mekanisme dan pengaturan penentuan ganti rugi atas kerugian yang dialami dalam sengketa lingkungan hidup diatur dalam Undang-Undang Nomor 32 Tahun 2009, dimana pertanggung jawaban terhadap kerusakan lingkungan hidup dipertanggung jawabkan melalui tanggung jawab mutlak terhadap kerugian yang telah terjadi. Tanggung jawab mutlak ini, pihak penggugat tidak perlu membuktikan unsur kesalahan serta dapat dibarengi dengan ketentuan beban pembuktian terbalik. Mengenai pedoman penghitungan kerugian lingkungan hidup akibat kerusakan lingkungan hidup diatur dalam Peraturan Menteri Lingkungan Hidup RI No. 7 Tahun 2014.
\end{abstract}

Kata Kunci: Ganti Rugi, Kerusakan Lingkungan Hidup, Penyelesaian Sengketa Keperdataan.

\begin{abstract}
Writing this journal article aims to find out how to model environmental dispute resolution through civil channels and to find out the mechanisms and arrangements regarding the determination of compensation for losses experienced in environmental disputes. The method used in this legal research is the method of normative legal research, by applying the analysis description technique that answers problems based on the analysis of legal and statutory materials. The results showed that, there are 2 models of environmental dispute resolution through civil channels that can be taken, namely the litigation route and the nonlitigation route. In dispute resolution through litigation, filing a lawsuit can be done through several lawsuit models, namely Individual Lawsuit, Class Representative Lawsuit, and Environmental Organization Lawsuit. Meanwhile, the non-litigation route can be carried out by means of negotiation, mediation, conciliation and arbitration. Regarding the mechanism and arrangement for determining compensation for losses suffered in environmental disputes is regulated in Law Number 32 of 2009, where responsibility for environmental damage is accounted for through absolute responsibility for the
\end{abstract}


losses that have occurred. This absolute responsibility, the plaintiff does not need to prove the element of error and can be accompanied by the provision of a reverse burden of proof. Regarding the guidelines for calculating environmental losses due to environmental damage, it is regulated in the Regulation of the Minister of Environment of the Republic of Indonesia No. 7 of 2014.

\section{Key Words: Compensation, Environmental Damage, Civil Dispute Resolution.}

\section{Pendahuluan}

\subsection{Latar Belakang Masalah}

Lingkungan hidup termasuk segala ekosistem didalamnya tidak akan pernah terlepas dari suatu permasalahan. Permasalahan lingkungan hidup memiliki akar permasalahan dengan kompleksitasnya tersendiri. Balik kepada permulaannya, awal dan akar permasalahan lingkungan hidup adalah permasalahan natural, yaitu suatu peristiwa yang merupakan bagian dari proses natural di alami tanpa ada keterlibatan manusia yang berupa bencana alam seperti tsunami, gempa bumi ataupun gunung meletus yang terjadi tanpa ada campur tangan manusia. Pada mulanya permasalahan lingkungan terjadi akibat suatu proses alami, lambat laun dalam perkembangannya, manusia menjadi salah satu faktor utama penyebab munculnya masalah terkait lingkungan hidup. Indonesia memiliki tingkat kerusakan dan kehancuran hutan dengan kurun waktu tercepat jika dibandingkan dengan negara lainnya. 72\% hutan asli Indonesia telah beralih fungsi dan musnah, serta sisanya masih dibayangi dengan ketakutan akan penebangan komersil dalam rangka perluasan lahan. Fenomena lain seperti berupa banjir, menjadi contoh konkrit mengenai dampak dari penebangan hutan dan pembuangan sampah sembarangan. ${ }^{1}$ Secara konstitusional, negara sudah membuat aturan terhadap perlindungan lingkungan hidup untuk kesejahteraan masyarakat berdasarkan Pasal $28 \mathrm{H}$ Ayat 1 UUD NRI Tahun 1945. Pasal ini menyatakan, "Setiap orang berhak hidup sejahtera lahir dan batin, bertempat tinggal, dan mendapatkan lingkungan hidup yang baik dan sehat".

Kerusakan lingkungan hidup menimbulkan beberapa kerugian terhadap pihak yang terdampak akibat dari kerusakan lingkungan hidup tersebut, maka pihak-pihak yang merasa dirugikan dan berdampak terhadap kehidupan mereka dari kerusakan lingkungan hidup itu dapat melakukan sengketa lingkungan hidup, yaitu dengan mengajukan gugatan ke pengadilan. ${ }^{2}$ Dalam sudut pandang Hukum Perdata, tindakan perusakan lingkungan hidup dapat diklasifikasikan sebagai perbuatan melawan hukum berdasarkan ketentuan Pasal 1365 KUHPerdata. ${ }^{3}$ Undang-Undang Republik Indonesia Nomor 32 Tahun 2009 Tentang Perlindungan dan Pengelolaan Lingkungan Hidup (selanjutnya disebut UU 32/2009), Pasal 87 ayat (1) menyatakan bahwa, "Setiap penanggung jawab usaha dan/atau kegiatan yang melakukan perbuatan melanggar hukum berupa pencemaran dan/atau perusakan lingkungan hidup yang menimbulkan kerugian pada orang lain atau lingkungan hidup wajib membayar ganti rugi dan/atau melakukan tindakan tertentu". Tetapi pada dewasa ini, masih ada beberapa masyarakat yang awam dan

1 Fitriyeni, Cut Era. "Penyelesaian Sengketa Lingkungan Hidup Melalui Pengadilan." Kanun Jurnal Ilmu Hukum 12, no. 3 (2010): 564-575.

2 Sawitri, Handri Wirastuti, and Rahadi Wasi Bintoro. "Sengketa Lingkungan dan Penyelesaiannya." Jurnal Dinamika Hukum 10, no. 2 (2010): 163-174.

3 Tjukup, I. Ketut, and I. Gusti Ayu Agung Ari Krisnawati. "Penyelesaian Sengketa Melalui Upaya Litigasi di Bidang Penegakan Hukum Lingkungan Keperdataan." ADHAPER: Jurnal Hukum Acara Perdata 4, no. 2 (2019): 163-185. 
kurang mengetahui mengenai pengajuan gugatan dalam sengketa kerusakan lingkungan hidup dan mengenai penentuan ganti rugi atas kerugian yang dialami.

Ada beberapa artikel jurnal yang sudah mengangkat tema mengenai penyelesaian sengketa lingkungan hidup, yaitu jurnal yang ditulis oleh Indah Sari, Jurnal Ilmiah Hukum Dirgantara-Fakultas Hukum Universitas Dirgantara Marsekal Suryadarma Volume 7 No. 1, (2016), dengan judul artikel SENGKETA LINGKUNGAN HIDUP DALAM PERSPEKTIF HUKUM PERDATA LINGKUNGAN dan juga jurnal yang ditulis oleh Muzakkir Abubakar, jurnal Fakultas Hukum Universitas Syiah Kuala Vol. 21, No. 1, (2019), dengan judul artikel HAK MENGAJUKAN GUGATAN DALAM SENGKETA LINGKUNGAN HIDUP. Akan tetapi, pada penulisan artikel jurnal ini pembahasannya akan berbeda terhadap 2 artikel jurnal yang disebutkan diatas. Pembahasan artikel jurnal ini lebih memfokuskan membahas mengenai model-model penyelesaian sengketa lingkungan hidup melalui jalur keperdataan dan juga akan membahas tentang mekanisme mengenai penentuan ganti kerugian atas kehilangan yang dialami dalam sengketa lingkungan hidup dan juga mengenai pengaturanpengaturan yang mengatur mengenai penentuan ganti rugi tersebut. Atas dasar halhal yang sudah disebutkan, dalam kesempatan kali ini maka difokuskan untuk menulis karya tulis dengan judul "MEKANISME PENENTUAN GANTI RUGI ATAS KERUSAKAN LINGKUNGAN HIDUP OLEH PERUSAHAAN: PENDEKATAN PENYELESAIAN SENGKETA KEPERDATAAN".

\subsection{Rumusan Masalah}

Penulisan karya ilmiah ini dirumuskan menjadi beberapa masalah, yakni:

1. Bagaimana model penyelesaian sengketa lingkungan hidup melalui jalur keperdataan?

2. Bagaimana mekanisme dan pengaturan mengenai penentuan ganti rugi atas kerugian yang dialami dalam sengketa lingkungan hidup?

\subsection{Tujuan Penulisan}

Tujuan penulisan karya ilmiah ini terhadap kedua permasalahan tersebut ialah:

1. Untuk mengetahi bagaimana model penyelesaian sengketa lingkungan hidup melalui jalur keperdataan

2. Untuk mengetahui mekanisme dan pengaturan mengenai penentuan ganti rugi atas kerugian yang dialami dalam sengketa lingkungan hidup

\section{Metode Penelitian}

Metode yang digunakan ialah metode penelitian yuridis normatif yakni penelitian hukum dibuat melalui penelitian bahan pustaka yang menjadi bahan utama untuk dapat dianalisa dengan membuat suatu penelusuran atas peraturan serta literatur yang memiliki hubungan serta kaitan dengan permasalahan yang sedang diteliti. ${ }^{4}$ Bahan pustaka yang dapat digunakan pada penulisan jurnal ini berupa bahan hukum primer serta bahan hukum sekunder yang menguraikan pembahasan dari bahan hukum primer. ${ }^{5}$ Dengan menggunakan teknik deskripsi analisis yang menjawab permasalahan melalui analisis bahan hukum serta perundang-undangan.

4 Soekanto, Soerjono dan Sri Mamudji. Penelitian Hukum Normatif1 (Suatu Tinjauan Singkat), (Jakarta, Rajawali Pers, 2001), 13.

5 Ali, H. Zainuddin. Metode Penelitian Hukum Cetakan Kesembilan, (Jakatra, Sinar Grafika, 2017), 23. 


\section{Hasil dan Pembahasan}

\subsection{Model Penyelesaian Sengketa Lingkungan Hidup Melalui Jalur Keperdataan}

Berdasarkan UU 32/2009, Pasal 1 angka 25 dinyatakan yakni "Sengketa lingkungan hidup adalah perselisihan antara dua pihak atau lebih yang timbul dari kegiatan yang berpotensi dan/atau telah berdampak pada lingkungan hidup". Subjek sengketa dari lingkungan hidup antara lain pelaku serta pihak korban yang merasakan dampak dari sengketa lingkungan, kegiatan yang memberikan ataupun akan berdampak terhadap lingkungan hidup dapat dikatakan sebagai objek sengketa. Pasal 84 UU 32/2009, dijelaskan mengenai beberapa cara untuk melakukan penyelesaian terhadap sengketa lingkungan hidup, yaitu:

1. Penyelesaian dengan cara litigasi maupun non-litigasi.

2. Pemilihan model yang dilaksanakan oleh pihak yang bersengketa secara suka rela untuk dapat menyelesaikan sengketa yang telah terjadi.

3. Pengajuan gugatan yang dilakukan secara litigasi baru bisa dilaksanakan apabila sudah diupayakan secara non-litigasi (diluar pengadilan) dan salah satu pihak dari yang berengketa menyatakan bahwa penyelesaian secara non-litigasi tidak berhasil.

\section{A. Penyelesaian Sengketa Lingkungan Hidup Melalui Pengadilan}

Jalur litigasi secara hukum keperdataan bertujuan untuk dapat menuntut ganti rugi yang telah ditimbulkan dan melakukan pemulihan terhadap lingkungan sebagai akibat kerusakan atau pencemaran lingkungan yang telah terjadi. Dalam pelaksanaan secara litigasi, baru dapat dilaksanakan jika ada pengajuan gugatan yang dilakukan oleh pihak yang merasa telah dirugikan oleh pihak yang diduga sebagai pemicu dari kerugian tersebut. Adapun syarat untuk pengajuan gugatan sengketa lingkungan hidup apabila telah memenuhi unsur, yaitu:

1) Terdapat suatu perbuatan yang melanggar hukum, dalam sengketa lingkungan hidup perbuatan tersebut melanggar aturan hukum yang ada, perbuataan melanggar hukum tersebut dapat berupa kerusakan terhadap lingkungan hidup

2) Terdapat kerugian yang dirasakan bagi pihak lain ataupun lingkungan hidup itu sendiri.

Menurut ketentuan Pasal 87 sampai dengan Pasal 93 UU 32/2009, memberikan penjelasan terkait penyelesaian terhadap suatu sengketa yang berhbungan dengan lingkungan hidup dapat dilakukan melalui jalur litigasi dilaksanakan untuk menetapkan ganti kerugian yang ditimbulkan, perbaikan terhadap keadaan lingkungan yang terusak, tanggung jawab mutlak, tenggang kadaluwarsan. Dalam mengajukan gugatan ke pengadilan dalam penyelesaian segketa lingkungan hidup dapat dilakukan dengan jalur pengadilan, serta dapat dilakukan melalui beberapa model gugatan, yaitu:

\section{Gugatan Perorangan}

Dalam Pasal 65 ayat (1) UU 32/2009 menyatakan "Setiap orang memiliki hak atas lingkungan hidup yang baik dan sehat sebagai bagian dari hak asasi manusia". Segala peristiwa yang memberikan dampak berupa udara kotor, polusi, dan sebagainya, hal tersebut menimbulkan kerusakan pada lingkungan hidup. Masyarakat terdampak dan dirugikan atas perbuatan tersebut memiliki hak menggugat terhadap pihak yang telah 
melakukan kerusakan lingkungan hidup tersebut. ${ }^{6}$ Warga terdampak secara langsung dan berhubungan dengan peristiwa, berkedudukan sebagai korban dapat menuntut yang bertujuan untuk mendapatkan kompensasi atau ganti rugi dan juga pemulihan kondisi seperti semula. Hak untuk melakukan gugatan yang dimiliki hanya dapat dipergunakan oleh subjek hukum apabila memiliki kepentingan hukum yang cukup. Pada Putusan Mahkamah Agung RI tanggal 7 Juli 1971 No. 294/X/Sip/1971 dijelaskan mengenai pengajuan gugatan dapat dilakukan oleh orang yang memiliki hubungan hukum. Kepentingan korban dalam sengketa lingkungan hidup dapat disamakan antara satu dengan korban yang lain untuk meminta ganti rugi, namun besarnya nilai kerugian yang dirasakan setiap korban yang berbeda-beda. ${ }^{7}$

\section{Gugatan Perwakilan Kelompok (Class Action)}

Berdasarkan UU 32/2009, penyelesaian untuk alur sengketa mengenai lingkungan hidup dibidang keperdataan melalui gugatan perwakilan kelompok (class action) diatur pada Pasal 91 yang menentukan bahwa, ayat (1) "masyarakat berhak mengajukan gugatan perwakilan kelompok untuk kepentingan dirinya sendiri dan/atau untuk kepentingan masyarakat apabila mengalami kerugian akibat pencemaran dan/atau kerusakan lingkungan hidup". ayat (2), "Gugatan dapat diajukan apabila terdapat kesamaan fakta atau peristiwa, dasar hukum serta jenis tuntutan di antara wakil kelompok dan anggota kelompoknya".

Pada ketentuan tersebut belum dilengkapi prosedur beracara secara class action, sehingga penerapan gugatan perwakilan kelompok dalam praktek peradilan perdata berpedoman pada Peraturan Mahkamah Agung Nomor 1 Tahun 2002 tentang Acara Gugatan Perwakilan Kelompok sebagai suatu cara pengajuan gugatan. Pengajuan gugatan kelompok dapat dilakukan dengan mekanisme satu atau beberapa orang yang mewakili kelompoknya untuk mengajukan gugatan baik bagi diri sendiri ataupun bersama dalam jumlah banyak, gugatan yang diajukan mewakili kesamaan fakta dan dasar hukumnya. Disamping Perma Nomor 1 Tahun 2002 itu, penerapan gugatan perwakilan kelompok (class action) dalam praktek peradilan perdata juga berpedoman pada Hukum Acara Perdata yang diatur dalam HIR/RBg dan peraturan perundangundangan, termasuk putusan-putusan hakim tentang class action. ${ }^{8}$

\section{Gugatan Organisasi Lingkungan Hidup (Legal Standing)}

Organisasi Lingkungan Hidup mempunyai hak gugat yang disebut degan legal standing. Hak gugat ini diatur dalam Pasal 92 UU 32/2009. Pada ayat (1) pasal tersebut menentukan "Dalam rangka pelaksanaan tanggung jawab perlindungan dan pengelolaan lingkungan hidup, organisasi lingkungan hidup berhak mengajukan gugatan untuk kepentingan pelestarian fungsi lingkungan hidup". Ayat (2) pasal tersebut menyatakan "hak mengajukan gugatan terbatas pada tuntutan untuk melakukan tindakan tertentu tanpa adanya tuntutan ganti rugi, kecuali biaya atau pengeluaran riil". ayat

6 Supramono, Gatot. Penyelesaian Sengketa Lingkungan Hidup di Indonesia, (Jakarta, Rineka Cipta, 2013), 69.

7 Sari, Indah. "SENGKETA LINGKUNGAN HIDUP DALAM PERSPEKTIF HUKUM PERDATA LINGKUNGAN." JURNAL ILMIAH HUKUM DIRGANTARA 7, no. 1 (2018): 1435.

8 Tjukup, I. Ketut, Dewa Nyoman Rai Asmara Putra, Nyoman A. Martana I. Putu Rasmadi, P. Arsha, and Kadek Agus Sudiarawan. "PENYELESAIAN SENGKETA LINGKUNGAN HIDUP MELALUI MEKANISME ACARA GUGATAN PERWAKILAN KELOMPOK (CLASS ACTION)." ADHAPER: Jurnal Hukum Acara Perdata 3, no. 2 (2018): 245-260. 
(3) menyebutkan "organisasi lingkungan hidup dapat mengajukan gugatan apabila memenuh persyaratan: (a) berbentuk badan hukum, (b) dalam Anggaran Dasar ditegaskan bahwa organisasi tersebut didirikan untuk kepentingan pelestarian fungsi lingkungan hidup, (c) telah melaksanakan kegiatan nyata sesuai dengan Anggaran Dasar paling singkat 2 (dua) tahun".

Dapat dilihat pada Gugatan Organisasi Lingkungan Hidup adalah suatu hak gugat organisasi lingkungan baik gugatan dalam bentuk perorangan atau kelompok yang dalam hal ini bertindak serta mewakili untuk kepentingan publik dan/atau lingkungan. Gugatan Organisasi Lingkungan Hidup terbagi atas dua macam, yaitu gugat organisasi (ground actie) untuk gugatan yang diajukan organisasi lingkungan dan private standing / citizen suit untuk warga negara yang memiliki hak karena telah dirugikan sehingga mampu bertindak menggugat atas kepentingan umum. ${ }^{9}$

\section{B. Penyelesaian Sengketa Lingkungan Hidup Melalui Jalur di Luar Pengadilan (Non Litigasi)}

Penyelesaian sengketa lingkungan hidup secara non litigasi dapat melalui pendekatan yang berupa:

1) Prevention atau pencegahan konflik

2) Management conflict atau pengelolaan konflik

3) Conflict resolution atau resolusi konflik

4) Settlement atau penyelesaian konflik, dan;

5) Alternative dispute resolution (ADR) atau penyelesaian sengketa alternatif. ${ }^{10}$

Dalam Pasal 85 Ayat (1) UU 32/2009, dijelaskan mengenai proses penyelesaian terhadap sengketa lingkungan hidup yang dilaksanakan dengan alur diluar pengadilan, diselenggarakan untuk menemui kata sepakat atas:

1) besaran dan wujud ganti rugi;

2) perbaikan pasca pencemaran dan/atau perusakan;

3) Penjaminan agar tidak terulangnya kembali pencemaran dan/atau perusakan; dan/atau

4) kegiatan pencegahan dampak negatif terhadap lingkungan hidup.

Tindakan-tindakan yang ada semata-mata sebagai langkah untuk mengembalikan fungsi dari pada lingkungan hidup yang sebelumnya telah rusak akibat dari kerusakan lingkungan hidup dapat dilakukan dengan melihat nilai-nilai yang tumbuh dan berkembang pada masyarakat setempat, untuk perbuatan tindak pidana yang telah termaktub pada Undang-Undang Lingkungan Hidup, penyelesaiannya tidak dapat dilakukan secara non-litigasi.

Penyelesaian sengketa diluar pengadilan (non litigasi) bertujuan untuk melindungan terhadap hak keperdataan dari setiap pihak yang bersengketa. Penyelesaian sengketa ini memiliki keunggulan cepat dan efisien terhadap waktu yang dipergunakan. Jika dibandingkan, penyelesaian sengketa non litigasi dan litigasi,

9 Machmud, Syahrul. Penegakan Hukum Lingkungan Indonesia, (Yogyakarta, Graha Ilmu, 2012), 201.

10 Rahmadi, Takdir. Hukum Lingkungan di Indonesia, (Jakarta, PT Raja Grafindo Persada, 2011), 287. 
kecenderungan lebih unggul pada penyelesaian secara non-litigasi, mengingat membutuhkan waktu lama dan biaya .tidak sedikit apabila menempuh jalur litigas. ${ }^{11}$

Terdapat beberapa bentuk dari Alternatif Penyelesaian Sengeketa (APS)/Alternative Dispute Resolution (ADR) yaitu: ${ }^{12}$

\section{1) Negosiasi}

Negosiasi merupakan suatu proses dalam mewujudkan kesepakatan antar para pihak yang bersengketa. Proses negosiasi dilaksanakan dengan perundingan langsung (dengan atau tanpa seorang kuasa) antara para pihak. Para pihak yang bersengketa akan mengadakan proses tawar-menawar untuk mencari jalan keluar dan kesepakatan.

\section{2) Mediasi}

Mediasi merupakan penyelesaian terhadap sengketa yang dilaksanakan melalui jalur alternatif dengan melibatkan pihak yang bersengketa dan pihak ketiga mediator. Dalam kebiasaan, pilihan mediasi diambil pasca upaya negosiasi dilaksanakan dan tidak menyelesaikan masalah yang ada. Mediator nantinya akan berkedudukan sebagai pihak penengah dari para pihak yang bermasalah, mediator akan memberikan bantuan berupa opini dan langkah-langkah yang yang baiknya ditempuh oleh pihak yang bersengketa yang selanjutnya disepakati oleh pihak yang bersengketa.

\section{3) Konsiliasi}

Konsiliasi adalah bentuk penyelesaian secara non-litigasi dengan melibatkan pihak yang bersengketa dan pihak ketiga yang disebut konsiliator. Konsiliator dapat terdiri dari seorang maupun beberapa orang. Konsiliator merupakan seseorang yang memiliki kompetensi sebagai seorang penengah serta pengalaman professional. Tugas konsiliator adalah memberikan bantuan dan pendapat bagi para pihak yang bersengketa yang berupa daftar alternatif langkah yang dapat di tempuh. Apabila para pihak yang memiliki sengketa sepakat pada pendapat yang diberikan oleh konsiliator, maka pilihan tersebut akan dituangkan dalam kesepakatan tertulis.

\section{4) Arbitrase}

Arbitrase merupakan suatu proses penyelesaian terhadap sengketa yang terjadi didalam bidang perdata dilakukan diluar pengadilan, didasarkan atas perjanjian arbitrase yang dibuat secara tertulis oleh para pihak yang bersengketa. Proses arbitrase melibatkan pihak-pihak yang memiliki sengkera dan pihak ketiga disebut sebagai arbiter. Sengketa akan diperiksa dan diniali oleh arbiter professional yang ahli pada bidang yang disengketakan oleh para pihak. ${ }^{13}$

\subsection{Mekanisme dan Pengaturan Mengenai Penentuan Ganti Rugi atas Kerugian yang Dialami dalam Sengketa Lingkungan Hidup}

Kewajiban yang untuk melakukan ganti kerugian atas suatu perbuatan melawan hukum yang dapat menimbulkan kerugian bagi orang lain atas suatu perbuatan yang telah dibuat disebut sebagai ganti rugi. ${ }^{14}$ Kerugian langsung yang ditimbulkan sebagai

11 Sawitri, Handri Wirastuti, dan Rahadi Wasi Bintoro, Op.cit., hlm: 163-174.

12 Diah, Marwah M. "Prinsip dan Bentuk-Bentuk Alternatif Penyelesaian Sengketa Di Luar Pengadilan." Jurnal Ilmiah Hukum dan Dinamika Masyarakat 5, no. 2 (2016): 111-122.

13 Kusuma, Kadek Dwika Tirta dan Suardita, I Ketut. "Tata Cara Pemanggilan Saksi dan Kewajibannya untuk hadir dalam proses pemeriksaan Arbitrase". Kertha Wicara: Journal Ilmu Hukum 8, no. 3 (2019): 1-16.

14 Pamuncak, Aristya Windiana. "Perbandingan Ganti Rugi dan Mekanisme Peralihan Hak Menurut Peraturan Presiden Nomor 65 Tahun 2006 dan Undang-Undang Nomor 2 Tahun 2012." Law and Justice 1, no. 1 (2016): 1-8. 
akibat kesalahan yang dilakukan tergugat dan diderita langsung oleh penggugat dapat dijadikan dasar hukum dalam menuntut upaya ganti rugi. Nilai ganti rugi yang dituntut penggugat nantinya dirinci dan dapat dibuktikan kebenaran dari nilai kerugiannya. Ganti rugi memiliki tujuan untuk mengembalikan kondisi penggugat seperti semula sedia kala.

Pengajuan ganti rugi dapat didasari dengan dasar Perbuatan Melawan Hukum maupun Wanprestasi. ${ }^{15}$ Ganti rugi dengan dasar wanprestasi terjadi akibat debitur yang cidera janji atas perjanjian yang disepakati. Dasar hukum untuk untuk melakukan ganti rugi, selaian para pihak telah membuat perjanjian serta diatur dalam KUHPerdata mulai dari Pasal 1243 sampai dengan 1252. Ganti rugi akibat perbuatan melawan hukum (PMH) merupaka perbuatan yang dibebankan kepada pihak yang telah melakukan suatu kesalahan dengan melanggar undang-undang yang ada dan menimbulkan kerugian bagi pihak lain.

Dalam Pasal 87 Ayat (1) UU 32/2009 mengatur mengenai ganti kerugian dimana berbunyi, "Setiap penanggung jawab usaha dan/atau kegiatan yang melakukan perbuatan melanggar hukum berupa pencemaran dan/atau perusakan lingkungan hidup yang menimbulkan kerugian pada orang lain atau lingkungan hidup wajib membayar ganti rugi dan/atau melakukan tindakan tertentu". Mengenai perbuatan melawan hukum berdasarkan ketentuan dari Pasal 1365 KUHPerdata, dimana PMH memiliki beberapa unsur, yaitu: ${ }^{16}$

1. Adanya perbuatan

2. Perbuatan tersebut bersifat melawan hukum

3. Adanya kesalahan dari pihak yang melakukan

4. Adanya kerugian bagi korban

5. Adanya hubungan kausalitas antara perbuatan dengan kerugian

Dari 5 unsur yang ada dalam PMH berdasarkan dengan Pasal 1365 KUHPerdata, dimana salah satu unsur tersebut yaitu unsur kesalahan memiliki penerapan yang berbeda dalam perkara lingkungan hidup. Perbedaan terletak pada pertanggung jawaban, dalam kerusakan lingkungan hidup dapat dilakukan tanggung jawab mutlak. Pada penerapan asas tanggung gugat mutlak biasanya bersamaan dengan pembuktian terbalik, kewajiban asuransi serta pembuktian plafond yang dapat merupaan batas maksimal untuk melakukan ganti kerugian. ${ }^{17}$ Dimana dalam ketentuan Pasal 88 dijelaskan, "Setiap orang yang tindakannya, usahanya, dan/atau kegiatannya menggunakan B3, menghasilkan dan/atau mengelola limbah B3, dan/atau yang menimbulkan ancaman serius terhadap lingkungan hidup bertanggung jawab mutlak atas kerugian yang terjadi tanpa perlu pembuktian unsur kesalahan". Ketentuan yang ada merupakan suatu hukum khusus atau lex specialis dan mengenyampingkan hukum umum atau lex generalis yang berupa adanya kewajiban untuk membuktikan adanya kesalahan dari pihak yang melakukan.

15 Slamet, Sri Redjeki. "Tuntutan Ganti Rugi dalam Perbuatan Melawan Hukum: Suatu Perbandingan dengan Wanprestasi." Lex Jurnalica 10, no. 2 (2013): 107-120.

16 Janis, Ignatius K. "Mekanisme Ganti Rugi Akibat Pencemaran Lingkungan Hidup Menurut Undang-undang Nomor 32 Tahun 2009." Lex Crimen 5, no. 5 (2016): 37-43.

17 Handayani, Emi Puasa, Zainal Arifin, and Saivol Virdaus. "Liability Without Fault Dalam Penyelesaian Sengketa Lingkungan Hidup Di Indonesia." ADHAPER: Jurnal Hukum Acara Perdata 4, no. 2 (2019): 1-19. 
Mengenai besaran nilai ganti rugi, dapat ditentukan sampai batas tertentu. Penting dipahami tata cara untuk melakukan penghitungan terhadap kerugian yang timbul sebagai dampak dari kerusakan lingkungan hidup. Peraturan Mentri Lingkungan Hidup Republik Indonesia Nomor 7 Tahun 2014 Tentang Kerugian Lingkungan Hidup Akibat Pencemaran dan/atau Kerusakan Lingkungan Hidup, Peraturan Menteri tersebut telah mengatur mengenai perhitungan ganti rugi akibat kerusakan lingkungan hidup. Sengketa kerusakan lingkungan hidup dapat diselesaikan melalui jalur litigasi maupun non litigasi, proses penyelesaian sengketa lingkungan hidup tetap diperlukan bukti bahwa telah terjadinya kerusakan lingkungan hidup. Bukti yang dapat dilampirkan harus berasal dari hasil sebuah penelitian, pengamatan yang dilakukan dilapangan ataupun berupa keterangan para ahli yang pendapatnya dapat dipertanggungjawabkan secara keilmuan.

Dalam UU 32/2009 menentukan mengenai tanggung jawab lingkungan (environmental responsibility). Tanggung jawab lingkungan meliputi masalah ganti rugi kepada orang dan/atau pemulihan lingkungan. Dari sini dapat dipahami bahwa environmental liability bisa bersifat privat dan juga sekaligus bersifat publik. ${ }^{18}$ Terdapat 2 kewajiban yang harus dipenuhi oleh pelaku pencemaran dan perusakan, yaitu tanggung jawab kepada perseorangan dan juga tanggung jawab yang berkaitan dengan urusan publik. Penentuan ganti rugi atas kerugian yang dialami dalam sengketa lingkungan hidup merupakan suatu nilai yang wajib dipertanggung jawabkan oleh pihak yang melakukan kerusakan lingkungan hidup jika terbukti di dalam pengadilan melakukan tindakan tersebut. Ganti rugi yang diakibatkan dari kerusakan pada lingkungan hidup tidak sebatas pihak yang melakukan gugatan atas kerugian yang telah dialaminya, tetapi juga menyangkut ganti rugi sebagai biaya pemulihan lingkungan hidup akibat dari dampak kerusakan yang telah dilakukannya.

\section{Kesimpulan}

Sengketa terhadap lingkungan hidup dapat diselesaikan melalui model penyelesaian jalur keperdataan yakni, secara litigasai maupun non litigasi. Pada penyelesaian sengketa secara litigasi, dalam mengajukan gugatan dapat dilakukan melalui beberapa model gugatan, yaitu Gugatan Perorangan, Gugatan Perwakilan Kelompok (Class Action), dan Gugatan Organisasi Lingkungan Hidup (Legal Standing). Sedangkan, pada proses penyelesaian sengketa melalui mekanisme non-litigasi dapat dilakukan melalui negosiasi, mediasi, konsiliasi, serta arbitrase. Mekanisme dan pengaturan mengenai penentuan ganti rugi atas kerugian yang dialami dalam sengketa lingkungan hidup diatur pada Pasal 87 ayat (1) UU 32/2009 dan Pasal 1365 KUH Perdata. Kerusakan terhadap lingkungan hidup pada akhirnya menimbulkan suatu dampak kerugian terhadap pihak lain, diwajibkan untuk membayar ataupun melakukan ganti rugi atas kerugian yang telah diperbuat ataupun melakukan suatu tindakan tertentu yang mempu mengembalikan kerugian yang diperbuat. Kerusakan terhadap lingkungan hidup dapat dipertanggung jawabkan melaui tanggung jawab mutlak terhadap kerugian yang telah terjadi. Tanggung jawab mutlak ini, pihak penggugat tidak perlu membuktikan unsur kesalahan serta dapat dibarengi dengan ketentuan beban pembuktian terbalik. Saran yang mampu disampaikan, diharapkan kedepannya mengenai model penyelesaian sengketa dan juga mekanisme penentuan

18 Hartanto, Heri, and Anugrah Adiastuti. "MEKANISME PENENTUAN GANTI KERUGIAN TERHADAP KERUSAKAN LINGKUNGAN HIDUP." ADHAPER: Jurnal Hukum Acara Perdata 3, no. 2 (2018): 227-243. 
ganti rugi atas kerusakan lingkungan hidup dalam penerapannya dapat lebih disosialisasikan kembali oleh pihak akademisi, pemerintah, maupun organisasi lingkungan hidup. Agar masyarakat tidak mengalami kebingungan jika terjadi permasalahan-permasalahan mengenai kerusakan lingkungan hidup untuk proses penyelesaian sengketa yang akan ditempuh dan lebih mengetahui bagaimana mekanisme dan pengaturan penentuan ganti rugi atas kerugian yang terjadi dalam sengketa lingkungan hidup.

\section{DAFTAR PUSTAKA}

\section{Buku}

Ali, H. Zainuddin. Metode Penelitian Hukum Cetakan Kesembilan, (Jakatra, Sinar Grafika, 2017)

Machmud, Syahrul. Penegakan Hukum Lingkungan Indonesia, (Yogyakarta, Graha Ilmu, 2012)

Rahmadi, Takdir. Hukum Lingkungan di Indonesia, (Jakarta, PT Raja Grafindo Persada, 2011)

Soekanto, Soerjono dan Mamudji, Sri. Penelitian Hukum Normatif (Suatu Tinjauan Singkat), (Jakarta, Rajawali Pers, 2001)

Supramono, Gatot. Penyelesaian Sengketa Lingkungan Hidup di Indonesia, (Jakarta, Rineka Cipta, 2013)

\section{Jurnal}

Diah, Marwah M. "Prinsip dan Bentuk-Bentuk Alternatif Penyelesaian Sengketa Di Luar Pengadilan." Jurnal Ilmiah Hukum dan Dinamika Masyarakat 5, no. 2 (2016): 111-122.

Fitriyeni, Cut Era. "Penyelesaian Sengketa Lingkungan Hidup Melalui Pengadilan." Kanun Jurnal Ilmu Hukum 12, no. 3 (2010): 564-575.

Handayani, Emi Puasa, Zainal Arifin, and Saivol Virdaus. "Liability Without Fault Dalam Penyelesaian Sengketa Lingkungan Hidup Di Indonesia." ADHAPER: Jurnal Hukum Acara Perdata 4, no. 2 (2019): 1-19.

Hartanto, Heri, and Anugrah Adiastuti. "MEKANISME PENENTUAN GANTI KERUGIAN TERHADAP KERUSAKAN LINGKUNGAN HIDUP." ADHAPER: Jurnal Hukum Acara Perdata 3, no. 2 (2018): 227-243.

Janis, Ignatius K. "Mekanisme Ganti Rugi Akibat Pencemaran Lingkungan Hidup Menurut Undang-undang Nomor 32 Tahun 2009." Lex Crimen 5, no. 5 (2016): 37-43.

Kusuma, Kadek Dwika Tirta dan Suardita, I Ketut. “Tata Cara Pemanggilan Saksi dan Kewajibannya untuk hadir dalam proses pemeriksaan Arbitrase". Kertha Wicara: Journal Ilmu Hukum 8, no. 3 (2019): 1-16.

Pamuncak, Aristya Windiana. "Perbandingan Ganti Rugi dan Mekanisme Peralihan Hak Menurut Peraturan Presiden Nomor 65 Tahun 2006 dan Undang-Undang Nomor 2 Tahun 2012." Law and Justice 1, no. 1 (2016): 1-8.

Sari, Indah. "SENGKETA LINGKUNGAN HIDUP DALAM PERSPEKTIF HUKUM PERDATA LINGKUNGAN." JURNAL ILMIAH HUKUM DIRGANTARA 7, no. 1 (2018): 14-35.

Sawitri, Handri Wirastuti, and Rahadi Wasi Bintoro. "Sengketa Lingkungan dan Penyelesaiannya." Jurnal Dinamika Hukum 10, no. 2 (2010): 163-174.

Slamet, Sri Redjeki. "Tuntutan Ganti Rugi dalam Perbuatan Melawan Hukum: Suatu Perbandingan dengan Wanprestasi." Lex Jurnalica 10, no. 2 (2013): 107-120. 
Tjukup, I. Ketut, and I. Gusti Ayu Agung Ari Krisnawati. "Penyelesaian Sengketa Melalui Upaya Litigasi di Bidang Penegakan Hukum Lingkungan Keperdataan." ADHAPER: Jurnal Hukum Acara Perdata 4, no. 2 (2019): 163-185.

Tjukup, I. Ketut, Dewa Nyoman Rai Asmara Putra, Nyoman A. Martana I. Putu Rasmadi, P. Arsha, and Kadek Agus Sudiarawan. "PENYELESAIAN SENGKETA LINGKUNGAN HIDUP MELALUI MEKANISME ACARA GUGATAN PERWAKILAN KELOMPOK (CLASS ACTION)." ADHAPER: Jurnal Hukum Acara Perdata 3, no. 2 (2018): 245-260.

\section{Peraturan Perundang-Undangan}

“Undang-Undang Dasar Negara Republik Indonesia Tahun 1945".

"Kitab Undang-Undang Hukum Perdata".

"Undang-Undang Nomor 32 Tahun 2009 Tentang Perlindungan Dan Pengelolaan Lingkungan Hidup (Lembaran Negara Republik Indonesia Tahun 2009 Nomor 140, Tambahan Lembaran Negara Republik Indonesia Nomor 5059)".

"Peraturan Mahkamah Agung Republik Indonesia Nomor 1 Tahun 2002 tentang Acara Gugatan Perwakilan Kelompok".

"Peraturan Mentri Lingkungan Hidup Republik Indonesia Nomor 7 Tahun 2014 Tentang Kerugian Lingkungan Hidup Akibat Pencemaran dan/atau Kerusakan Lingkungan Hidup". 